УДК 663.1

(C) 2012

Дорочкевич Н. В., кандидат сільськогосподарських наук

Донецький національний університет

Шевкопляс В. М., кандидат хімічних наук

Інститут фізико-органічної хімії і вуглехімії ім. Л. М. Литвиненка НАН України

\title{
ВИЗНАЧЕННЯ НОВИХ ВИСОКОПРОДУКТИВНИХ ІЗОЛЯТІВ ГРИБА PLEUROTUS OSTREATUS (JACQ.: FR.) KUMMER ЗА ДОПОМОГОЮ КОЕФІЦІЕНТА ГАБІТУСУ
}

\section{Рецензент - кандидат біологічних наук Н. М. Пірко}

\begin{abstract}
Здійснено оиінку господарсько-біологічних показників нових ізолятів гриба P. ostreatus за умов інтенсивного культивування на твердому вуглецевому субстраті - лушпинні соняшника, як найбільш розповсюдженому в Україні. Встановлено, щуо всі культури гливи звичайної здатні утворювати плодові тіла без температурного шоку і додаткового впливу зовнішніх факторів. Виявлено морфобіологічні особливості нових ізолятів гриба P. ostreatus, а саме: за розміром та кількістю плодових тіл $i$ зростків, формою шапинки. Зроблено розрахунок коефіцієнта габітусу плодових тіл тливи звичайної, за результатами якого встановлено найбільш перспективні ізоляти В-99 і К-99 для промислового грибівництва, порівняно з контрольним штамом HK-35.
\end{abstract}

Ключові слова: штами, ізоляти, інтенсивне культивування, врожайність, плодове тіло, коефіиієнт габітусу.

Постановка проблеми. На сучасному етапі розвитку грибівництва України перспективним $\epsilon$ промислове культивування їстівних базидіоміцетів, зокрема гриба Pleurotus ostreatus (Jacq.: Fr.) Kummer, добре відомого під назвою глива звичайна. Цей гриб має високі показники життєздатності, добре пристосовується до будь-якої зміни довкілля та вуглецевого субстрату і тому в штучних умовах має просту технологію вирощування, що дає можливість в достатній кількості отримувати 3 нього харчовий білок, який є альтернативним до білків рослинного або тваринного походження [1]. Одним із основних завдань сучасного грибівництва $є$ підвищення врожайності плодових тіл від впровадження нових перспективних штамів гливи звичайної. Такий підхід припускає проведення цілеспрямованого пошуку нових плодових тіл гливи звичайної в різних кліматичних умовах з метою подальшого їх використання в скрінінгових дослідженнях $[6,9]$.

Нині застосовується відомий метод інтенсивного культивування гливи в пакетах із невели- кою кількістю субстрату, що є напіввиробничим методом, максимально наближеним до промислових умов, який дає змогу виявити найперспективніші штами гриба $[5,10]$. Одним із напрямів сучасного дослідження $є$ оцінка нових ізолятів $P$. ostreatus до плодоношення в штучних умовах за коефіцієнтом габітусу плодових тіл гриба $[5,10,11]$.

Аналіз останніх досліджень і публікацій, у яких започатковано розв'язання проблеми. Морфологічні ознаки плодових тіл, їх габітус $\epsilon$ одним 3 елементів ідентифікації штамів, які визначають його потенційні можливості й залишаються незмінними незалежно від умов вирощування [2]. В роботах авторів [3, 10] вивчено коефіцієнт габітусу гриба роду Agaricus, за яким можливо оцінити розміри, пропорційність плодових тіл гриба та їх товарні якості. Високі показники коефіцієнта габітусу різних штамів даного гриба свідчили про найкращі його товарні якості й перспективність для промислового культивування. Для гриба роду Pleurotus надавалася недостатня увага, хоча він належить до шапинкових грибів, у яких плодове тіло чітко розділено на шапинку і ніжку [9]. Також у літературі відсутні дані щодо взаємозв'язку між коефіцієнтом габітусу плодових тіл та урожайністю цього гриба.

Мета і завдання досліджень. Мета дослідження - визначення коефіцієнта габітусу нових ізолятів гриба $P$. ostreatus за умов інтенсивного культивування на твердому вуглецевому субстраті - лушпинні соняшника (як найбільш розповсюдженому в Україні) та використання цього коефіцієнта в якості індикатора задля знаходження нових, більш перспективних, ізолятів для промислового грибівництва.

Матеріали та методи досліджень. Дослідження проведено на базі кафедри фізіології рослин Донецького національного університету у спеціальному приміщенні 3 контрольованими 
параметрами мікроклімату, які не залежали від факторів зовнішнього середовища. Обліки, аналізи та спостереження за умов інтенсивного культивування гриба проводили за стандартними загальноприйнятими методиками [7]. Для роботи взято нові природні ізоляти гриба P. ostreatus K-99, Р-01, В-99, ВК-2000, Р-15, С-2000, КЕ-2001, виділені з плодових тіл, зібраних із деревинних субстратів у різних географічних районах Донецька, Донецької та Курської областей, а також новий штам 420 із колекції кафедри фізіології рослин. Для контролю використано штам НК-35, який занесено до Державного реєстру сортів України, що широко культивується у промисловому масштабі [4]. Інтенсивне культивування проведено на вуглецевому твердому субстраті (лушпинні соняшника) в поліпропіленових пакетах розміром 20х30 см із масою 1,5 кг. Обліковою ділянкою був кожний мішок. Варіанти розміщували методом повної рендомізації. Повторність дослідів триразова. Лінійні показники визначали як середні значення вимірів усіх плодових тіл із кожного варіанта 3 подальшим розрахунком коефіцієнта габітусу за формулою С. Ф. Негруцького зі співавторами [3]: $\mathrm{K}=\frac{X-Y}{X-Z}$, де: $\mathrm{K}-$ коефіцієнт габітусу, у. о.; $\mathrm{X}$ - діаметр шапинки, см; Y - довжина ніжки до шапинки, см; Z - максимальний діаметр ніжки, см. Урожайність гриба підраховували за відношенням маси свіжих плодових тіл до маси вологого субстрату (г/кг). Статистичну обробку даних проводили за допомогою дисперсійного аналізу та множинного порівняння середніх за Данетом [8] і комп'ютерної програми Origin 7.

Результати досліджень. За результатами досліджень інтенсивного культивування на лушпинні соняшника встановлено, що нові ізоляти гриба P. ostreatus здатні утворювати плодові тіла без температурного шоку та додаткового впливу зовнішніх факторів. Плодові тіла всіх ізолятів відрізнялися між собою за кольором і формою шапинки, причому колір примордіїв був інтенсивнішим, порівняно з плодовими тілами, і варіював від блакитного до темно-сірого. Форма плодового тіла мала вигляд від округлої до воронкоподібної, що цілком співпадає 3 описом гриба у літературі $[1,7]$. Плодові тіла нових ізолятів гриба $P$. ostreatus відрізнялися між собою за розміром та кількістю плодових тіл і зростків. Кількість зростків коливалася від 1 до 3 на одному мішку. Кількість плодових тіл варіювала від 10 до 25 штук в одному зростку.
За результатами досліджень встановлено, що всі нові ізоляти гриба за терміном повного обростання субстрату незначною мірою відрізнялися між собою і засвоювали всю поверхню субстрату за 1012 діб після інокуляції. Появу примордій першої хвилі плодоношення виявлено в усіх ізолятів на 14-30-у добу, другої - на 30-64-у добу, що пов'язано з їх морфобіологічними особливостями. Раніше всіх примордії першої хвилі утворювалися в ізолятів Р-15, ВК-2000 і у нового штаму 420 (1415-та доба), що несуттєво відрізняло їх від контрольного штаму НК-35 (18-та доба). Пізніше утворення примордіїв, порівняно з НК-35, спостерігалося в ізолятів В-99, К-99 і Р-01 (26-30-та доба). Така ж послідовність спостерігалася щодо появи примордіїв другої хвилі плодоношення.

Аналіз отриманих даних свідчить, що нові ізоляти гриба P. ostreatus відрізнялися між собою за показниками плодового тіла. Найбільшу масу плодового тіла мали ізоляти В-99 і К-99 (17,9 і 17,4 г відповідно), що в 1,9 разу вище порівняно зі штамом НК-35 (9,2 г). Найменшою маса плодового тіла була в ізолятів С-2000 і штаму 420 - 8,4 та 7,8 г відповідно. Найбільший діаметр шапинки був також у ізолятів В-99 і К-99 - 7,1 і 7,6 см відповідно. У штаму НК-35 діаметр шапинки становив 6,1 см і незначною мірою відрізнявся від інших штамів. За розміром довжини ніжки всі досліджені штами були майже однаковими.

Розраховані коефіцієнти габітусу плодових тіл (К, у. о.) культур гриба P. ostreatus свідчать, що найкращі товарні якості притаманні новим ізолятам К-99 і В-99, що в 1,4-1,3 рази вище порівняно зі штамом НК-35 (рис. 1). Низькі показники коефіцієнта габітусу мали ізоляти С-2000 і Р-15 та штам ізолят 420. Інші ізоляти незначно відрізнялися між собою за цим показником, але він був теж вищим, ніж у штаму НК-35.

Другу частину досліджень було спрямовано на встановлення взаємозв'язку між лінійними показниками плодового тіла нових ізолятів гриба P. ostreatus та їх продуктивністю (рис. 1-4). Отримані дані свідчать про взаємозв'язок між коефіцієнтами габітусу першої та другої хвиль плодоношення культур P. ostreatus iз коефіцієнтом кореляції $\mathrm{R}=0,724$, який можна описати лінійним рівнянням регресії:

$$
y=-(0,08 \pm 0,23)+(0,88 \pm 0,33) x \text { (рис. } 1) \text {. }
$$

Це вказує на те, що незалежно від хвилі плодоношення лінійні показники плодового тіла, а саме: діаметр шапинки та ніжки і довжина ніжки завжди мають розміри в межах, обумовлених морфобіологічними особливостями кожного штаму гливи звичайної. Отримані результати 


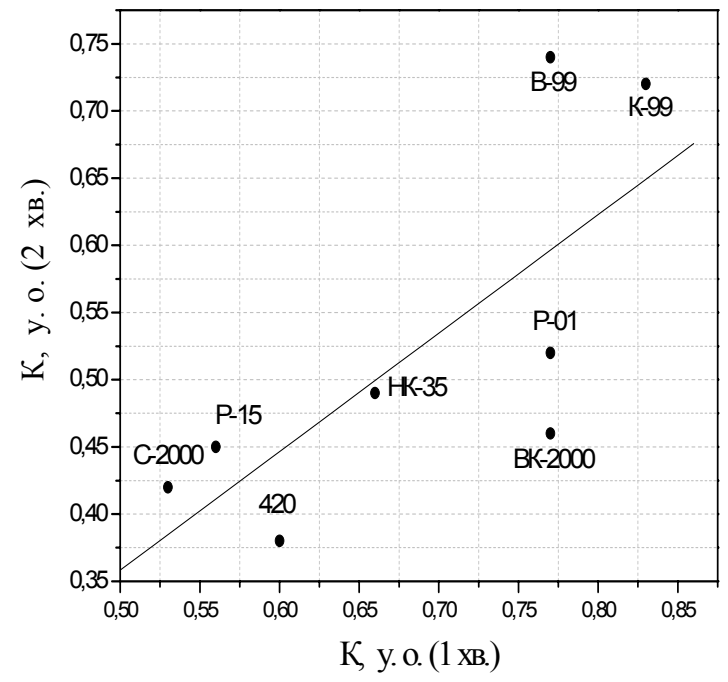

Рис. 1. Взаємозв'язок між коефіцієнтами габітусу першої (К, у. о. (1 хв)) та другоӥ $(К, y$. о. (2 хв)) хвиль плодоночення нових P. ostreatus в умовах інтенсивного культивування на лушпинні соняшника

дають підстави зробити припущення, що коефіцієнт габітусу (К, у. о.) - відносно постійний морфобіологічний показник, який не залежить від інших факторів плодоношення гриба P. ostreatus. Це підтверджується встановленим взаємозв'язком між коефіцієнтом габітусу та урожайністю нових штамів $P$. ostreatus в умовах інтенсивного культивування на лушпинні соняшника 3 високим коефіцієнтом кореляції $\mathrm{R}=0,908$, який описується рівнянням $\mathrm{y}=-(57,94 \pm 43,1)+(370,56 \pm 69,63) x$ (рис. 2).

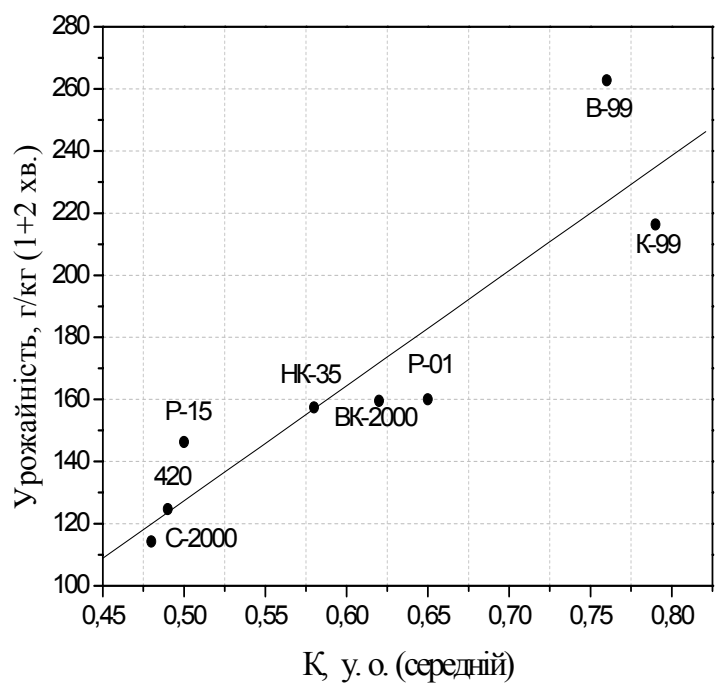

Рис. 2. Взаємозв'язок між коефіцієнтом

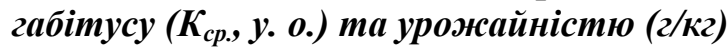
нових ізолятів P. ostreatus в умовах інтенсивного культивування на лушпинні соняшника
Взаємозв'язок, який виявлено, дає змогу скоротити час дослідження гриба від пошуку нового штаму в природі до впровадження його в промислове грибівництво, а саме: за розрахунком коефіцієнта габітусу гриба вже на попередній стадії відбору вирахувати майбутню урожайність будьякої дослідженої культури.

За результатами експериментів встановлено також прямий взаємозв'язок між першою і другою хвилями плодоношення, що описується рівнянням $y=(10,48 \pm 10,81)+(0,206 \pm 0,08) x \quad 3$ $\mathrm{R}=0,723$ (рис. 3 ).

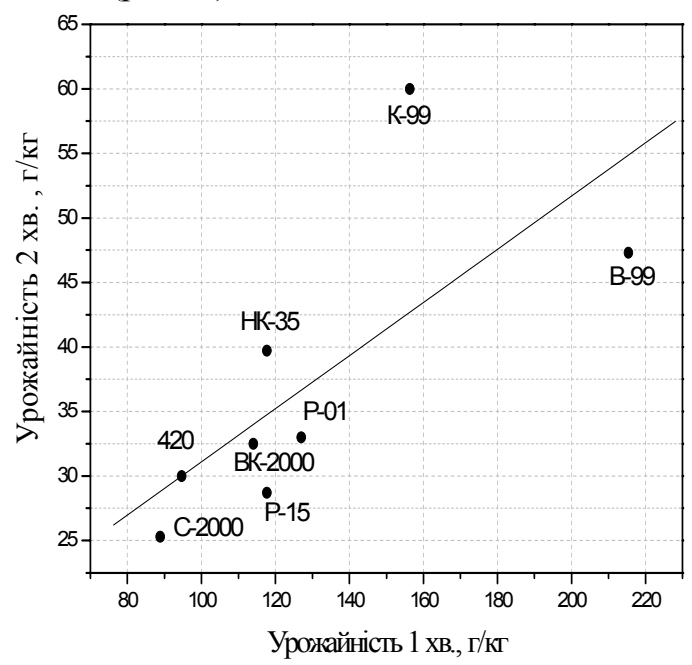

Рис. 3. Взаємозв'язок мізж урожайністю (2/кг) першої і другої хвиль плодоношення для нових ізолятів P. ostreatus в умовах інтенсивного культивування на лушпинні соняшника

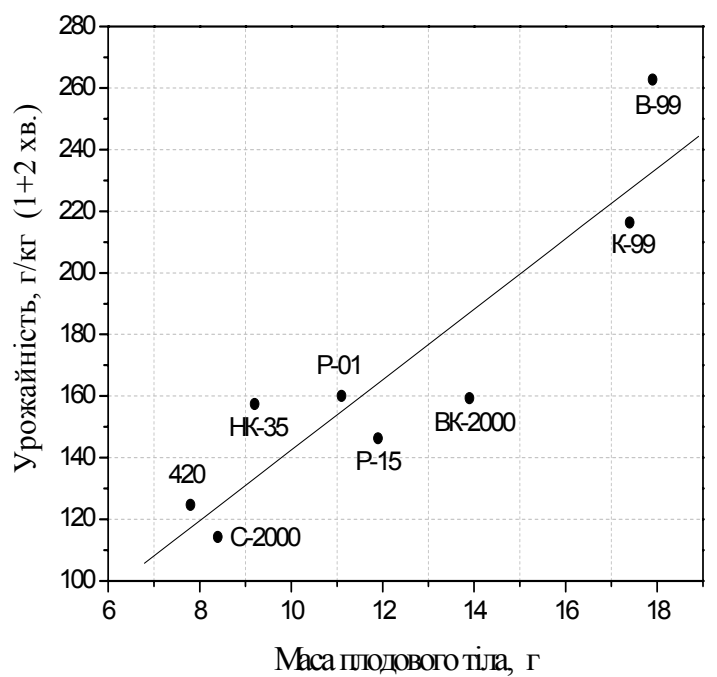

Рис. 4. Взаємозв'язок між масою плодового тіла (2) і урожсайністю (2/к2) в умовах інтенсивного культивування нових ізолятів гриба P. ostreatus на лушпинні соняшника 


\section{СІЛЬСЬКЕ ГОСПОДАРСТВО. РОСЛИННИЦТВО}

На підставі отриманих даних можна зазначити: по-перше, урожайність першої хвилі корелює 3 урожайністю другої хвилі плодоношення і $є$ максимальною для штамів К-99 і В-99; по-друге, за параметрами плодового тіла, які генетично обумовлені, всі культури знаходяться у межах, притаманних для кожного штаму, тобто урожайність нових штамів гливи звичайної певною мірою визначається морфобіологічними особливостями гриба.

За результатами досліджень встановлено взаємозв'язок між масою плодового тіла й урожайністю першої і другої хвиль плодоношення штамів P. ostreatus в умовах інтенсивного культивування на лушпинні соняшника, що описується лінійним рівнянням (рис. 4):

$$
y=(28,1 \pm 26,9)+(11,43 \pm 2,12) \times 3 \mathrm{R}=0,911 \text {. }
$$

Видно, що найбільш урожайні ізоляти гливи звичайної К-99 і В-99 мають також і найбільшу масу плодового тіла. Ізоляти 3 низькими показниками урожайності характеризуються малою масою плодового тіла. Таким чином, маса плодового тіла $\epsilon$ морфобіологічним показником гриба, який знаходиться в межах, властивих для кожної дослідженої культури.

\section{БІБЛІОГРАФІЯ}

1. Бисько Н. А. Биология и культивирование грибов рода вешенка / Н. А. Бисько, И. А. Дудка. - К.: Наукова думка, 1987. - 148 с.

2. Вдовенко C. A. Морфологія плодових тіл виду Pleurotus / С. А. Вдовенко, О. І. Кепко // Зб. наук. праць Вінницького держ. агр. ун-ту. - 2004. № $19 .-$ C. 12-15.

3. Горное грибоводство / [С. Ф. Негруцкий, Ю. А. Шапочник, П. А. Сычев и др.]; под ред. С. Ф. Негруцкого. - Донецк: РИП «Лебедь», 1995. - 168 с.

4. Державний реєстр сортів рослин придатних для поширення в Україні: за станом на 15.04.2009 року. / Мін. агр. політики Укр., Держ. служба з охорони прав на сорти рослин. - Офіц. вид. - К.: ТОВ «Алефа», 2009. - С. 192-193. (Бібліотека офіційних видань).

5. Дорошкевич Н. В. Господарсько-біологічна оцінка нових штамів гриба Pleurotus ostreatus (Jacq.: Fr.) Kummer: автореф. дис. ... на здобуття канд. с.-г. наук.: спец. 06.01.06 «Овочівництво» / Н. В. Дорошкевич - К., 2010. - 20 с.

6. Лавлинский Л. В. Введение в культуру дикорастущих видов вешенки (Pleurotus) как метод сохранения и рационального использования их природного биоразнообразия / Л.В.Лавлинский // Проблемы сохранения разнообразия растительного покрова Внутренней Азии. - Улан-Удэ,
Висновки. Таким чином, усі досліджені штами придатні для вирощування на лушпинні соняшника в умовах інтенсивного культивування. Водночас вони відрізняються між собою за показниками плодоношення, урожайності й лінійними параметрами плодового тіла. Встановлено, що продуктивність гриба залежить від морфобіологічних особливостей ізоляту і має хвилеподібний характер плодоношення. Перша i друга хвилі плодоношення різняться між собою за показниками урожайності. Найбільш продуктивною є перша хвиля плодоношення, що становить понад 70-80 \% від загальної урожайності плодових тіл (рис. 3).

На підставі отриманих даних можна стверджувати, що коефіцієнт габітусу (К, У. о.) є відносно постійним морфобіологічним показником гриба, який не залежить від хвилі плодоношення та його продуктивності. Взаємозв'язок, який виявлено між масою плодового тіла та урожайністю, можна використовувати практично для визначення найперспективніших ізолятів гриба вже на попередньому етапі дослідження.

2004. - Ч. 2. - С. 86-88.

7. Методы экспериментальной микологии / [И. А. Дудка, С. П. Вассер, И. А. Элланская]; под ред. В. И. Билай. - К.: Наукова думка, 1982. $550 \mathrm{c}$.

8. Приседський Ю. Г. Статистична обробка результатів біологічних експериментів / Ю. Г. Приседський. - Донецьк: Кассиопея, 1999. - 210 с.

9. Сравнительный анализ природных изолятов вида Pleurotus ostreatus / О.В.Штаер, Ю. С. Белоконь, М. М. Белоконь [и др.] // Микробиол. 2005. - Т. 74, № 2. - С. 231-238.

10. Цизь О. М. Підбір високопродуктивних штамів і субстратів для вирощування печериці двоспорової (Agaricus bisporus /J. LGE/Imbach) в умовах України: автореф. дис. ... канд. с.-г. наук: спец. 06.01.06 «Овочівництво»/ О. М. Цизь. - K., 1999. - 20 c.

11. Цизь О. М. Господарсько-біологічна оцінка штамів гливи звичайної [Електронний ресурс] / О. М. Цизь, Є. В. Лящук // Наукові доповіді НАУ 2007. - № 3 (8). - 7 с. - Режим доступу: http://www.nbuv.gov.ua/e-Journals/nd/2007-

3/07tomboe.pdf

12. Цилюрик A. В. Грибы лесных биоценозов: Атлас / А. В. Цилюрик, С. В. Шевченко. - К.: Вища шк. - Головне вид-во, 1989. - 255 с. 